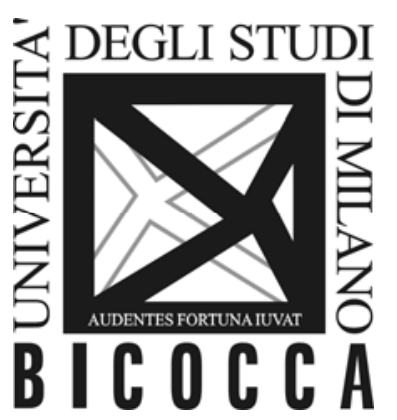

\author{
DEPARTMENT OF ECONOMICS, \\ MANAGEMENT AND STATISTICS \\ UNIVERSITY OF MILAN - BICOCCA
}

DEMS WORKING PAPER SERIES

\title{
Is it the way they use it? Teachers, ICT and student achievement
}

Simona Comi, Marco Gui, Federica Origo,

Laura Pagani, Gianluca Argentin

No. 341 - June 2016

Dipartimento di Economia, Metodi Quantitativi e Strategie di Impresa

Università degli Studi di Milano - Bicocca

http://dems.unimib.it/ 


\title{
Is it the way they use it? \\ Teachers, ICT and student achievement
}

\author{
Simona Comi ${ }^{\text {a }}$, Marco Gui ${ }^{\mathrm{b}}$, Federica Origo ${ }^{\mathrm{c}}$, Laura Pagani ${ }^{\mathrm{d}}$, Gianluca Argentin ${ }^{\mathrm{e}}$ \\ a. University of Milan-Bicocca, Piazza dell'Ateneo Nuovo 1, 20126, Milan, Italy. E-mail: simona.comi@unimib.it \\ b. University of Milan-Bicocca, Piazza dell'Ateneo Nuovo 1, 20126, Milan, Italy. E-mail: marco.gui @ unimib.it \\ c. University of Bergamo, Via dei Caniana 2, 24127 Bergamo, Italy. E-mail: federica.origo@unibg.it \\ d. University of Milan-Bicocca, Piazza dell'Ateneo Nuovo 1, 20126, Milan, Italy. E-mail: laura.pagani@unimib.it \\ e. Catholic University of Sacred Hearth, Largo Gemelli 1, 20123, Milan, Italy. E-mail: gianluca.argentin@unicatt.it
}

\begin{abstract}
We provide evidence on whether ICT-related teaching practices affect student achievement. We use a unique student-teacher dataset containing variables on very specific uses of computer and ICT by teachers matched with data on national standardized tests for $10^{\text {th }}$ grade students. Our identification strategy relies on a within-student between-subject estimator and on a rich set of teacher's controls. We find that computer-based teaching methods increase student performance if they help the teacher to obtain material to prepare lectures, if they channel the transmission of teaching material, if they increase students' awareness in ICT use and if they enhance communication. Instead, we find a negative impact of practices requiring an active role of the students in classes using ICT. Our findings suggest that the effectiveness of ICT at school depends on the actual practice that teachers make of it and on their ability to integrate ICT into the teaching process.
\end{abstract}

Keywords: Teaching practices, Student performance, ICT, Between-subject variation Jel Classification: I21

\footnotetext{
* Corresponding author. Tel.: +39 0264487461 .
} 


\section{Introduction}

In the past two decades, many countries have launched national and local programs for Information and Communications Technology (ICT) in schools. In nearly all countries, actions within the ICT education strategies are funded primarily from the public budget. Budgets are allocated between equipment and human resources, but the purchase and maintenance of equipment and facilities have often taken precedence in expenditure (Eurydice 2011).

Major investment amounts over the past 20 years have brought ICT into nearly all schools in the most advanced OECD countries. In 2009, 97\% of the teachers in public primary and secondary schools in the US had one or more computers located in the classroom every day (93\% of them with Internet access), and the ratio of students to computers in the classroom was 5.3 to 1 (Gray et al. 2010). In the same year, in Europe, at least $75 \%$ of the students had the availability of one computer for up to four students. The latest EU-survey on ICT in schools confirms that ICT has become more pervasive also in European countries. In the 2011-12 school year, there were approximately twice as many computers per one hundred students in secondary schools compared with 2006, and the share of schools with websites, e-mail for both teachers and students and a local area network has been steadily increasing at all levels of education (European Commission 2013).

In view of the large public outlays for ICT in schools in many countries, there has been an increasing literature trying to identify the effect of ICT at school on learning. Most recent studies exploit the exogeneity of national or local programs aimed at increasing ICT infrastructure in schools and find either little or no effect (Checchi et al. 2015, Barrera-Osorio and Linden 2009, Cristia et al. 2012). A partial exception is Machin et al. (2007), who investigate the effects of a change in the rules governing ICT funding across different school districts of England and find a positive impact on primary school students' performance in English and science, but not in mathematics. The above papers do not specify how ICT is used. A few studies have gone beyond the analysis of the effects of the availability of ICT equipment and looked at the role of computer-aided instructions (CAI), namely the use of computers to teach, for instance using specific software programs to promote learning. These studies often employ a simple dichotomous variable capturing the usage of CAI and generally find no statistically significant effects on student performance (Angrist and Lavy 2002, Rouse and Krueger 2004), except for mathematics achievement, particularly in early school years (Barrow et al. 2009, Banerjee et al. 2007).

Falck et al. (2015) is the only study analyzing the effect of three different classroom computerbased activities performed by students on their academic performance. They show that the null 
effect of classroom computers on student achievement is a combination of positive and negative effects of different computer uses.

Altogether, these findings appear to suggest that ICT use is not more effective than traditional teaching methods. A potential explanation is that the introduction of computers may have displaced alternative investments of school resources and the related educational activities which, had they been maintained, would have prevented a decline in student achievement. Another reason for the weak ICT effects in schools may be the difficulty to actually integrate ICT into educational practices. The availability of ICT-related educational devices (such as computers, tablets, software or educational programs) is not enough to improve student achievement, but it is the actual practice that teachers make of these devices - together with teachers' digital literacy, level of ICT skills and ICT-related beliefs - that makes the difference (OECD 2001).

The importance of what teachers do in the classroom has been emphasized in the recent literature on the effects of teaching practices on students' academic performance, which has focused on the effect of traditional versus modern teaching style. The results generally show that teaching style matters (Aslam and Kingdom 2011, Schwerdt and Wuppermamm 2011, Zakharov et al. 2014), but the empirical evidence is not conclusive with regard to the comparative effectiveness of modern and traditional practices (Van Klaveren 2011, Lavy 2011). In view of this, more research is needed on the impact of ICT-related teaching practices on pupils' performance. Bringing together the literature on the effects of ICT at school and the literature on the effects of teaching practices on student performance, we provide insight into the impact of very specific uses of computers and ICT by teachers on student achievement in math and Italian language. Using a unique and rich matched student-teacher dataset on Italy, we adopt an identification strategy that exploits within-student between-subject variation to control for unobserved students' traits. Furthermore, the specific Italian institutional setting, prohibiting class choice within schools, helps us circumvent the potential non-random sorting of students to teachers because the actual class groupings are random.

Our paper makes a number of important contributions to the existing literature on the effect of ICT at school. First, we consider a great array of ICT-related teaching methods, covering a broad spectrum of teaching-related activities both in the classroom and outside, both with students and alone. The survey we are using contains many detailed questions on the use of ICT in teaching that allows us to identify five distinct groups of teaching practices: "backstage activities", such as preparing and printing files to be distributed in class; computer use for knowledge transmission during lessons, such as projecting slides or sharing files with students; 
teaching practices implying active involvement of students, for instance through the use of general or specific software; media education practices, such as teaching students how to use social media or blogs; and communication-enhancing activities, favoring teacher-to-teacher collaboration and communication with students and families.

Second, when estimating the effects of teaching practices on students' achievement we control for both a subjective and an objective measure of teachers' digital skills. This latter is measured by means of teachers' scores in a detailed ICT performance test. Indeed, each practice might have a different effect depending on teachers' ICT knowledge, also because the lack of it could make teachers anxious, primarily in classrooms of students whose ICT knowledge is higher than their own. Moreover, we have information regarding past ICT-related training, which may affect both teachers' ICT knowledge and its pedagogical use through specific practices.

Finally, an important factor we are able to control for are teachers' beliefs about ICT use for teaching and learning. Existing evidence demonstrates that these latter affect the frequency of ICT use in schools more than the availability of infrastructures: students taught by teachers who are positive about ICT use in education but face low access and high obstacles to utilizing it at school report more frequent use of ICT during lessons compared to students taught by teachers having high access to ICT but being less positive about its usefulness for teaching (European Commission 2013).

We find that the effect of the computer-based teaching practices outlined above is quite heterogeneous. They increase student performance primarily if they channel the transmission of knowledge to students or if they are used to teach students a critical use of the Internet. We also find a positive effect of communication-enhancing practices, while a negative effect is found for practices requiring more active involvement by students in classrooms. We find heterogeneous effects of computer-based practices by subject (Italian language and math). Our results are not driven by specific groups of teachers such as those who strongly believe in the usefulness of ICT for teaching or those who are very familiar with it.

In the case of practices requiring active involvement of students in classrooms, we obtain similar results using an alternative dataset that allows to fully control for teacher subjectinvariant characteristics exploiting within-teacher within-student variation.

The remainder of the paper is structured as follows: the next section describes the data and the main variables used in the empirical analysis; Section 3 presents a description of the computerbased teaching methods that we consider, and it provides some theoretical insight into their potential effects on students' learning; Section 4 explains the identification strategy, also paying attention to the specific institutional setting of the Italian school system; Section 5 presents the 
main results; a number of robustness checks and extensions are discussed in Section 6. Concluding remarks and some policy implications are provided in the last section.

\section{Data and descriptive statistics}

We use an ad hoc ICT survey conducted on a representative sample of students in their second year of upper secondary school $\left(10^{\text {th }}\right.$ grade $)$ in the Lombardy region, the most populated and economically advanced Italian region. The survey was conducted in April 2012 on a sample stratified by school type and geographical (provincial) position. The response rate of the sampled schools was $94 \%$. None of the students present during the administration of the survey refused to fill the questionnaire. The final sample contains 2,025 students from 100 classrooms randomly drawn from 51 upper secondary schools.

In addition to standard information on socio-demographic characteristics, on past and current academic performance ${ }^{1}$ and on extra-curricular activities, the survey provides an in-depth description of the kind of digital devices owned and used, of the frequency and type of use of the Internet and of digital devices and computer labs in school.

We then matched information from this ad hoc ICT survey with data from the Italian National Institute for the Evaluation of the School System (INVALSI), which annually conducts standardized tests to assess pupil achievement at various grades. ${ }^{2}$ We consider the math and Italian language tests administered to $10^{\text {th }}$ grade pupils at the end of the 2011/2012 school year, along with a pupils' questionnaire. The latter contains additional information on students (such as their level of confidence with questions such as those usually asked in the national tests), which can complement those provided by the other survey we are using. The math and Italian language standardized test scores provided by INVALSI are our dependent variables. ${ }^{3}$ In merging the students' ICT survey with the national test scores, we drop some observations with missing values in the national test score.

Through a second ad hoc survey, we collected information on teachers socio-demographic characteristics (gender, birth year, highest education level obtained, field of study and graduation grade), job position (experience, tenure, type of contract, the number of hours taught weekly and the subject taught), training (including ICT-related one) and the reasons for

\footnotetext{
${ }^{1}$ Among other questions, we asked each student the average grade obtained in Italian language, math, foreign language and science at the end of the first term of the same school year.

${ }^{2}$ National standardized tests were introduced in Italian schools in 2008.

${ }^{3}$ Math and Italian language constitute the main subjects in Italian schools and they serve as key indicators of academic performance.
} 
teaching, which we employ as a proxy for motivation. The questionnaire then specifically focuses on teachers' use of ICT outside of their jobs, asking how frequently they use a computer, how many hours they spend on the Internet daily and whether they have a Facebook profile. The most relevant part of the survey for our research asks teachers how often they use computers for a wide array of teaching-related practices, such as creating and projecting slides during classes, assembling digital material to be delivered to students, showing students specific educational websites or using a PC to communicate with colleagues, students and their families. The teachers are also asked whether they use educational software and whether they help students with ICT-related problems or explain how to conduct an Internet search using encyclopedias or websites. Then, teachers report how many hours per month they utilize an interactive whiteboard, a PC with a projector or a PC to work outside of the classroom. The final part of the questionnaire relates to teachers' opinions about the use of ICT as a tool to facilitate learning and asks for a self-evaluation of their ICT-related knowledge. ${ }^{4}$

At the end of the survey, a standardized test is administered to assess some of the main aspects of teachers' digital knowledge. The test has been developed by educational and ICT experts and it is an updated version of the test used in Gui and Argentin (2011). The test consists of 15 closed-ended questions. The specific digital skill that is evaluated is the "critical digital skill", that is, the teachers' ability to assess the reliability of webpage content or to identify correctly the sources and the risks related to Internet use. More specifically, teachers were asked to analyze website addresses and browser search results and to prove their knowledge of the functioning of popular websites among youth, such as Facebook, YouTube, Yahoo Answers or Wikipedia. ${ }^{5}$ We computed a normalized score describing teachers' digital knowledge based on the number of correct answers provided in the test.

After keeping only math and Italian language teachers, we merge the student dataset with the teacher dataset using a classroom identifier as the merging code.

\footnotetext{
${ }^{4}$ The specific question is as follows: All in all, do you think you are prepared to use the new ICTs as a teacher? Please answer using a 10-point scale (where 1 is not prepared at all, 10 is absolutely prepared).

${ }^{5}$ Examples of questions are the following two: 1) In your opinion, who writes Wikipedia entries? Choose only one of the following four possible answers: a. Those who are registered on the Wikipedia website and were accepted as collaborators; $b$. The creators of the website and other paid employees; c. There are no limitations: anyone can write them; d. Only a pool of experts chosen by Wikipedia. 2) Are the following sentences true or false? a. When you publish something on Facebook, you can make it accessible only to some of your Facebook friends; b. Information on Yahoo Answers is reliable because published answers were checked by experts; c. You can sign a contract with YouTube to get money for the videos you upload.
} 
We keep in the sample only those classes for which we observe both math and Italian language teachers and end up with 868 students (1,736 subject /students observations) and 94 teachers (47 for each subject). ${ }^{6}$

\section{TABLE 1 AROUND HERE}

Panel A of Table 1 reports the main descriptive statistics of a set of standard teachers' characteristics by subject. Italian language teachers are slightly younger and more educated and graduated with higher marks compared with math teachers. They also teach more hours per week in the considered classes. When we look at the choice of becoming a teacher, we can see that approximately 33 percent of Italian language teachers and 47 percent of math teachers pursued this career because of their passion for the subject. Conversely, 44 percent of Italian language teachers and 36 percent of math teachers chose this career because they wanted to teach or work with young people. The remaining share in each sample became teachers because of the lack of other job opportunities or because that type of job was responding to their own needs.

Table 1 (Panel B) also highlights that, on average, the students in our sample perform better on the national test of Italian language than that of math: as can be observed clearly in Figure 1, the within-student difference in the test scores is almost always positive (only $8 \%$ of the students exhibit a better performance in math). Similarly, the average grade in the first term is slightly higher in Italian language than in math. A number of explanations are consistent with this result: for example, students may be more competent in Italian language than in math or the first may be an easier subject than the latter. Furthermore, in Italy, it may also be the case that students are better trained in Italian language than in math to answer questions such as those on the national test. Actually, 45 per cent of the students in our sample have declared being familiar with the type of questions usually asked on the national test of Italian language, while the corresponding share for math drops to 26 per cent (see Table 1, Panel B) ${ }^{7}$.

\footnotetext{
${ }^{6}$ This operative sample does not differ from the original one with regard to the main students' characteristics. In particular, both the average grade in the first term of the school year and the average national test score are not statistically different in the two samples.

${ }^{7}$ Written math exams in Italian secondary schools are generally open questions or standard problems, while they rarely test problem solving and logical thinking, which are instead the core skills tested in most questions of the national test of math.
} 
To address this issue and make the score in the two subjects comparable, as in previous studies, we standardize the national test scores by subject (Aslam and Kingdom 2011). We will employ this standardized variable as the dependent variable of the following econometric analysis.

\section{FIGURE 1 AROUND HERE}

In Table 2, we focus on teacher ICT variables by subject. Quite interestingly, Italian language teachers performed on average better than math ones in the test on critical digital knowledge, but their subjective perception is lower. Compared to math teachers, Italian language teachers have a lower probability of attending an ICT-related training course, spend more hours on the Internet, and have a higher propensity to use a PC every day at home and to have a Facebook profile. A great majority of Italian language teachers believe that ICT is useful in preparing lectures, while only approximately one-half of math teachers share this opinion. Regardless of the subject taught, two out of three teachers are in favor of ICT use in teaching, and one out of three thinks that ICT introduced an important change in teaching. At the same time, only 15 percent of math teachers and 5 percent of Italian language ones believe that ICT had a positive effect on one's own teaching. A greater percentage of math teachers feel that their school is in favor of ICT introduction, while a greater share of Italian language teachers perceive some type of hostility ${ }^{8}$.

Finally, Italian language teachers use the interactive whiteboard (IWB) while teaching less hours per month and the PC with a projector more hours per month than math teachers do. There is no difference in the use of a PC in class on their own.

TABLE 2 AROUND HERE

\section{Identifying ICT-related teaching practices}

With regard to the use of ICT in teaching, we asked teachers how often they used their personal computer to conduct specific activities while preparing for or during classes. For each question, we report the distribution of answers separately for the two subjects in table A1 in the Appendix. The overall picture is rather rich and heterogeneous. Some of the practices are widely diffused,

\footnotetext{
${ }^{8}$ The reference category here is teachers who perceived neither hostility nor encouragement towards the introduction of ICT in their own school.
} 
such as preparing tests or printouts, while other are very infrequent, such as enrolling in online training courses. Some practices display wide differences by subject: for example, it is more likely that math teachers use educational software than Italian language ones, while the contrary is true when we look at preparing printouts or teaching how to use an online encyclopedia.

These practices are clearly correlated with one another for several reasons, such as the school policy towards the use of ICT in teaching, the nature and contents of the subject taught, individual teaching style and other teacher characteristics. To summarize the great amount of available information and to ease interpretation of the main results, we run a Principal Component Analysis (PCA) on the original sample of approximately 600 teachers, those that answered all of the items considered in the analysis. Kane et al. (2011) builds on the same approach used in the present study.

We adopted an exploratory approach considering all of the items investigating teacher use of ICT. We selected 19 items, considering their communality and factor loadings. We kept the first five components that emerged from the analyses, which are those with an eigenvalue greater than one (a standard criterion). This model explain $62 \%$ of the global amount of variance. The lowest communality is 0.38 , and each item is strongly associated only with one component ${ }^{9}$. Table 3 reports the associations between each item and the five components.

\section{TABLE 3 AROUND HERE}

The first component loads practices that imply the use of a personal computer during lessons, such as using slides or other digital material (video, audio or website) in class or sharing files with students (not printed or to be printed), so that ICT is employed to deliver information more efficiently, and that is why we named it knowledge transmission practices. The second component, labelled media education, loads practices aimed to produce skills that are not directly linked to the subject, such as the awareness of digital risks (evaluation of website content or how to avoid viruses), privacy rules or netiquette in social media. The third

\footnotetext{
${ }^{9}$ There are three exceptions. "Use of internet to prepare lectures" enters both the backstage activities and the use of pc in class, while "Teach how to avoid viruses" and "Teach how to evaluate the dependence of website content" are associated with media education and active involvement of students in class. The nature of these practices justifies their association to more than one component and makes these double associations very reasonable.
} 
component loads practices requiring an interaction among the teacher, the students and ICT devices, such as utilizing common or specific software in class, explaining how to study with the Internet or how to consult an online encyclopedia. Indeed, these are activities in which each student is "activated", i.e., assisted by the teacher in utilizing the technology to reach a particular goal, such as writing text or solving an equation. We labelled this factor active involvement. The fourth component loads background practices usually performed out of the classroom, such as preparing printouts, tests or lectures, and we call it backstage activities. Finally, the last component, labeled communication, pertains to the communication aspect of ICT, such as utilizing e-mail to communicate with students, family or colleagues or reading online formal communication by the ministry or the school board.

While such practices have been so far almost unexplored in the economic literature, the educational literature provides some theoretical insight and evidence on their potential effects on students' achievement. We refer to this literature to interpret the empirical results presented in the following sections.

With regard to knowledge transmission practices, it has been shown that computer use during lessons as a support for teachers pushes them to plan their lessons more efficiently (Higgins et al. 2005, Balanskat et al. 2006) and makes lessons more attractive for students (Ramboll Management 2006, Balanskat et al. 2006), clearly improving intermediate outcomes such as motivation and behavior (Condie and Munro 2007). The "visual appeals" of projected presentations appear to be the main contributor to this improvement (Smith et al. 2006). However, some have cast doubts on the persistence of this association, claiming that a "novelty factor" could be at work and that consequently, the effect could vanish when technology in schools is no longer a novelty (Digregorio and Sobel-Lojeski 2009).

As far as we know, there is no direct evidence on the association between media education practices and learning performance. However, the presence of ICT in the classroom is likely to facilitate a debate between students and their teachers on digital risks and opportunities, whose level of awareness seem particularly poor among adolescents (Calvani et al. 2012, Gui and Argentin 2011, Van Deursen and van Dijk 2009). Furthermore, there is evidence that digital supportive teachers tend to have more digitally aware students (Argentin et al. 2013) and that, in turn, a higher level of students' critical digital skills has a positive impact on their learning outcomes (Pagani et al. 2015).

Evidence on ICT-related practices requiring students' active involvement demonstrates that teachers usually do not fully exploit the creative potential of ICT, for instance engaging students more actively in the production of knowledge (Balanskat et al. 2006). The active use of ICT by 
students during lessons actually opens unexplored horizons in the student-teacher relationship. Maybe due to the complexity of the re-organization of teaching that an active use of ICT in the classroom demands, no evidence of positive impacts have emerged so far. On the contrary, a number of studies have actually found a negative association between learning outcomes and the frequency of ICT use by students at school or for school-related purposes (OECD 2011, Biagi and Loi 2013).

The impact of ICT using backstage activities on students' learning is twofold: on the one hand, the enormous and easy availability of textual and audiovisual effects can make lessons more complete and attractive; on the other hand, ICT can help teachers to customize their teaching more effectively. In an evaluation of the "Laptops for teachers" program of the British Government (2002-2004), teachers who had been equipped with laptops report having extended their ability to access resources and having saved time in lesson planning and preparation (Cunningham et al. 2003). Furthermore, teachers believe that preparing their lessons online has positive effects on the quality of their teaching (Ramboll Management 2006, Condie and Munro 2007).

Finally, research on the evaluation of ICT investment educational policies demonstrates that pupils and teachers appear to benefit from ICT-related communication practices between school and families (Condie and Munro 2007), and teachers perceive positive effects on teaching quality when ICT is employed to enhance communication with the other colleagues (Ramboll Management 2006). Nonetheless, only a small proportion of teachers, even when they make extensive use of ICT, report that they exploit the new technologies to increase collaboration with their colleagues, for instance, co-producing knowledge with other teachers inside and outside the school (OECD 2001).

\section{Empirical strategy}

To assess the effect of ICT-related teaching practices, we estimate the following specification of the standard education production function:

$$
y_{i j k}=\alpha+\beta_{1} I C T_{i j k}+\beta_{2} X_{i j k}+\beta_{3} S_{i j k}+\beta_{4} T_{i j k}+\varepsilon_{i j k}
$$


where $y$ is the test score of student $i$ in subject $j$ in school $k$, ICT is a vector of variables measuring the teacher ICT-related practices, $X$ is a vector of student characteristics, $S$ is a vector of school characteristics, and $T$ is a vector of teacher (and class) characteristics.

The error term $\varepsilon$ captures all of the unobserved factors influencing student performance, and it can be specified as follows:

$$
\varepsilon_{i j k}=\mu_{i}+\theta_{j}+\varphi_{k}+v_{i j k}
$$

where $\mu, \theta$ and $\varphi$ are, respectively, student, teacher and school time-invariant unobserved factors.

Estimation of equation [1] by OLS yields biased estimates if the unobserved factors are correlated with the variables in the ICT vector. This may be the case when neither teachers nor students are randomly distributed across schools (and across classes within schools) or when the adoption of ICT teaching practices is influenced by teachers' unobserved characteristics that also affect student achievement.

Endogenous sorting may arise because families choose specific schools for their children, and in some cases, they may also choose specific classes within a school, also on the basis of the teacher's quality and reputation. There is evidence showing that teachers prefer to work in schools with higher-achieving students, while they have heterogeneous preferences in terms of other students' observable characteristics, such as race and ethnicity (Hanushek 2004). Schools that are able to employ more effective teachers can in turn attract the highest achieving students and, hence, the unobserved students' heterogeneity is likely to inflate differences between schools in teacher quality. Despite this evidence of positive sorting between "good" teachers and "good" students, predicting the direction of the actual bias is difficult because, within schools, it also depends on the principal's objectives (Hanushek and Rivkin 2012): an egalitarian principal would place the higher quality teachers in classes with more disruptive children, while a principal who wants to retain the senior staff would match the more experienced teachers with the best students.

In our case, the specific institutional setting characterizing upper secondary education in Italy allows us to partially address the problem of endogenous matching between teachers and students: once families choose the school for their children, the latter are usually randomly assigned to a certain class - regardless of families or children's preferences for specific teachers or schoolmates. Hence, the class is not identified by a certain grade, but by a subsection of a 
certain year. Furthermore, the class is the same for all of the subjects taught and for the entire duration of high school: minor changes each year are due to students who have to repeat a year (this happens frequently in high schools) or who change school (a rare event) or who move to another town (an exceptional event). In this perspective, the same group of students (and teachers) could expect to be together for five years. Each class does everything together, staying all day in the same room; it is the teachers who go from classroom to classroom, except those whose subjects require labs or other special equipment. Everyone in a class takes the same courses because there are no electives in Italian high schools: the pool of subjects is determined by the type of high school and program initially chosen. If the student realizes that this is not what she is really interested in, she will change the program or even the school. This is usually done by the end of the first year of high school (i.e., $9^{\text {th }}$ grade) because later changes are usually very costly in terms of needed prerequisites for the new program/school, often requiring starting again from the first year.

Although the features of the institutional setting attenuate the problem of sorting between students and teachers, student achievement may be influenced by (unobserved) student, teacher and school factors. To address these sources of endogeneity, we follow the approach proposed by Dee $(2005,2007)$ and employ a within-student between-subject estimator, which allows us to fully control for the unobserved heterogeneity of both schools and students by taking differences between two subjects (in our case, Italian language and math, named I and M, respectively) in the following way:

$y_{i I k}-y_{i M k}=\alpha_{I}-\alpha_{M}+\beta_{1 I} I C T_{i I k}-\beta_{1 M} I C T_{i M k}+\left(\beta_{2 I}-\beta_{2 M}\right) X_{i}+\left(\beta_{3 I}-\beta_{3 M}\right) S_{i}+$ $\beta_{4 I} T_{i I k}-\beta_{4 M} T_{i M k}+\omega_{i}$

where: $\omega_{i}=\left(\theta_{I}-\theta_{M}\right)+\left(v_{i I}-v_{i M}\right)$

If we assume, as in Dee (2005), that the coefficients across subjects are equal ${ }^{10}$, equation [5] reduces to:

$$
y_{i I k}-y_{i M k}=\alpha_{I}-\alpha_{M}+\beta_{1} \Delta I C T_{i}+\beta_{4} \Delta T_{i}+\omega_{i}
$$

${ }^{10}$ As in previous studies, we allow the constant to differ across subjects. 
where identification of the coefficients relies on differences between subjects for the same student and on uncorrelation between the error term and the right hand side variables. ${ }^{11}$

Note that the second term in brackets of the error term in equation [4] may still contain student subject-specific unobserved factors (such as a differential aptitude toward each subject), which influence student performance and can be correlated with ICT teaching practices. To consider this potential source of endogeneity, we add to equation [5] some subject-specific student variables, namely the grade in the first term of the year in each subject, the familiarity with questions like those usually asked in the national tests and their beliefs relative to the importance later in life of each subject. The first variable transforms the equation into a kind of value-added specification.

With this estimator, we fully control for both school and class unobserved heterogeneity, but we cannot rule out potential endogeneity caused by unobserved teacher-specific factors. We address this problem exploiting the richness of the survey and controlling for a number of teacher characteristics (such as gender, age, education, training, work experience, tenure, type of contract, weekly hours taught), including some controls usually not available in previous studies, such as a proxy for teacher's innate ability (captured by their graduation grade) and for their motivation (captured by the main reason for which they chose to become teachers).

As mentioned above, another source of endogeneity of ICT-related practices may be due to self-selection of teachers into ICT adoption. In fact, those who employ ICT are likely to be teachers with more (unobservable) easiness with, love for, and ability with ICT or strong beliefs on the effectiveness of ICT in teaching; these characteristics may also influence student achievement - or they may be correlated with other unobservable characteristics that affect student achievement. This would lead to biased estimates of the coefficient $\beta_{1}$ in equation [5]. We address this issue in three ways. First, we control for the teacher ICT use and knowledge, both subjective and objective, and for teacher beliefs on the role of ICT in schools. We thus partially consider the unobserved component of the teacher specific error term that could be related to the adoption of ICT teaching practices. In fact, extensive literature exists in educational studies about teachers' perceived usefulness of ICT and the subsequent ICT adoption (see Scherer et al. 2015 for review and discussion). Perceived usefulness can be considered a behavioral belief, which forms the prerequisite for acting out behavior (Chien et

${ }^{11}$ Starting from Dee $(2005,2007)$, the within-student between-subject estimator has been widely used to account for selection effects in studies on the effect of teaching practices (Aslam and Kingdom 2007, Schwerdt and Wuppermann 2011, Van Klaveren 2011, Lavy 2015 and Falck et al. 2015). 
al. 2014). The perceived usefulness of ICT in teaching appears to be affected also by selfefficacy: teachers who perceive themselves as competent in utilizing ICT perceive the use of ICT as useful. Moreover, this relation stresses the importance of teachers' perceptions of their competences for their intention to use ICT (Lee and Lee 2014).

Second, we run robustness checks to test whether our main results are driven by teachers who are more familiar with the use of ICT or with stronger beliefs on the importance and usefulness of new technologies in schools and teaching. Finally, we estimate equation [5] employing a different dataset, TIMMS 2011, in which we have students' science and math test scores for the last year of junior high school. In this grade, in Italy, the same teacher teaches these two subjects, so we can add to the specification a teacher fixed effect and control for the timeinvariant component of unobservable teacher traits that may affect both ICT adoption and student achievement. ${ }^{12}$

As a final point, one could argue that the assumption of equal coefficients across subject used to derive equation [5] may be unrealistic, and the effect of different ICT teaching practices may be quite different in math and Italian language. For example, using specific software may be more effective in teaching math, while teaching how to consult a media encyclopedia may be more relevant for learning Italian language. To consider a potential heterogeneous effect of different ICT teaching practices by subject, we relax the assumption of a common treatment effect and estimate the following more flexible specification:

$y_{i I k}-y_{i M k}=\alpha_{I}-\alpha_{M}+\beta_{1 I} I C T_{i I k}+\beta_{1 M}\left(-I C T_{i M k}\right)+\beta_{4} \Delta T_{i}+\omega_{i}$

where all of the variables have the same meaning as in equation [5], but we allow the effect of ICT teaching practices to differ across subjects.

\section{Results}

Table 4 presents results of estimating equation [5] using the ICT-related practices we computed from the principal component analysis. We cluster standard errors at the classroom level throughout the paper. The reported estimates were obtained after standardizing each factor; hence, each coefficient could be interpreted as the effect of a one standard deviation increase in

\footnotetext{
12 This is not the case in upper secondary schools, where math and science are taught by two different teachers. Hence, even if we had data on the science teacher, we could not control for teacher fixed-effect with our data.
} 
that factor on student achievement. We first consider the five factors together with a set of standard teacher characteristics (gender, age, education, college final grade, a polynomial of the second order for experience and tenure, weekly teaching hours and their motivations) and teacher ICT-related variables (subjective and objective ICT knowledge, their beliefs on ICT and teaching, how much they use technology and whether they attended an ICT-related training course) (column 1). In column (2), we add controls for students' subject-specific characteristics. Regardless of the specification used, we find that the five factors are both jointly (as shown by the F-tests at the bottom of the two columns) and individually significant, apart from backstage activities. All of the considered ICT teaching practices influence student achievement positively, with the exception of those requiring active involvement of students in the classroom.

More specifically, our estimates in column (2) show that ICT-related practices involving knowledge transmission and those enhancing communication have the greatest positive effect on student achievement: an increase of one standard deviation in these practices is associated with an increase in student's test score of slightly less than one third of a standard deviation, corresponding, respectively, to a 4.2 and 4.5 increase on a 100-point scale. A similar increase in practices aimed at developing the critical use of ICT causes an improvement of the test of approximately one-fifth of a standard deviation. Should we move a teacher from the first quartile to the third in the distribution of the knowledge transmission practices factor, we could gain an increase of 6.5 percentage points in student achievement. On the contrary, an increase of one standard deviation in the practices requiring active involvement of the student in the use of ICT in the classroom reduces the test score by almost $30 \%$ of a standard deviation. This result confirms that - at current conditions - there could be a decrease in learning performance when ICTs are used intensively by students at school (OECD 2011).

\section{TABLE 4 AROUND HERE}

To sum up, ICT-related teaching practices increase student performance if they channel the transmission of knowledge, if they increase digital awareness or critical digital skills among students and if they accelerate and make it easier communication with students, families and colleagues. On the contrary, they do not significantly affect student performance if they help the teacher to obtain further material to prepare her lectures and they may actually be detrimental for student achievement if they require a more active involvement of students in using ICT in the classroom. 
To see if we can reconcile our results with the previous literature on ICT adoption, we move a step forward and try to see whether other less-refined and more general measures of ICT use produce similar results. In the Italian school setting, we cannot use the availability of IWBs or PCs in classes because both math and Italian language lessons are usually taken in the same classroom. Thus, we use alternative aggregates of the five factors or of the original 19 practices to measure the mere use of ICT by teachers in the two subjects, regardless of the specific teaching practices actually adopted. The main estimates of this exercise are reported in Table 5 , where the columns differ only for the indicator of general use of ICT in the classroom that is considered. In column (1) to (5) we use, respectively, the standardized sum of the five factors, the number of practices employed among the original 19 ones (following Falck et al. 2015), the number of practices that are used intensively, a dummy equal to 1 if at least one of the original 19 practices is employed intensively, and a dummy equal to 1 if the teacher makes any use of ICT in the classroom (at least one hour a month). Regardless of the definition employed, the general use of ICT in the classroom has no statistically significant effect on student performance, and in most specifications (i.e., columns 1, 4 and 5), the estimated coefficient is close to zero.

In general, these results are in line with the educational literature mentioned above and confirm that the adoption of ICT per se is not necessarily beneficial for student learning, suggesting that student achievement will not benefit from simply increasing ICT availability and infrastructure indiscriminately.

\section{TABLE 5 AROUND HERE}

Finally, we estimate Equation [6] and test for the existence of heterogeneous effects of ICT teaching practices by subject. In Table 6, we report the coefficients of interest for our preferred specification. Our estimates show that ICT teaching practices enhancing communication and knowledge transmission significantly increase student performance only in the case of math, while their effect on Italian language is not statistically significant. On the contrary, the negative effect of practices requiring an active involvement of the students in the use of ICT is much larger and statistically significant in the case of Italian language. These results seem to suggest that the new technologies are more effective for student learning when they are employed to transmit concepts and knowledge in scientific subjects, while active use by students is particularly detrimental in the humanities, in which the contents and approach of the subject are more likely to favor an unproductive use of the Internet. 


\section{TABLE 6 AROUND HERE}

\section{Robustness checks}

Previous results have been obtained using a within-student between-subject estimator, which allows us to fully control for unobserved heterogeneity at both the school and student level by obtaining differences between ICT-related teaching practices in math and Italian language. We controlled for teacher characteristics exploiting the richness of the survey that allowed us to control for a number of teacher variables, including proxies for teachers' innate ability, their motivation, their use of ICT and their beliefs about the use of ICT in schools. Despite this, we cannot rule out that there may be other unobserved factors that influence both the adoption of specific computer-based teaching methods and students' outcomes. To test the robustness of our results to potential additional endogeneity, we perform two robustness checks.

First, we test whether our main results are entirely driven by teachers who strongly believe in the usefulness of the new technologies in teaching and learning or by those who use intensely ICT and who perceive to be extremely skilled in the use of it. Exploiting the rich information available in our dataset on whether and how the teachers employ ICT in and outside the classroom, we create a dummy equal to 1 if the teacher is in favor of utilizing ICT for background activities, for teaching and for studying, and believes ICT has changed teaching in general and has had positive effects on her own teaching. We name this variable "Believer" because it identifies the teachers who deeply feel that the new technologies have changed or will change positively their way of teaching and education in general. We then create a second dummy, labeled "Heavy user", that takes a value of one if the teacher has a Facebook profile, uses a PC every day, surfs the net for more than one hour a day and has a relatively high subjective evaluation of her own ICT knowledge (higher than 6). With this variable, we want to capture whether teachers utilize ICT extensively and whether they are confident about their ability to use computers. Compared to other teachers, both the "Believer" and the "Heavy user" are likely to use more frequently all of the five ICT teaching practices considered, except for the backstage activities in the case of the "Heavy users" (see Table A2 in the Appendix).

In Table 7, we report the main estimates obtained by having these dummies interact with the five factors measuring ICT teaching practices. In the first column, we report the interactions with the "Believer" dummy, and in the second one, with the "Heavy user" dummy. For each factor, the interaction effect should be interpreted as the differential effect for the "Believer" (column 1) and the "Heavy user" (column 2) with respect to other teachers. In both cases, the 
sign and significance of the intercepts' coefficients confirm our previous results. The interaction effects for the "Believer" are not statistically significant with the exception of media education, for which we find a lower effect with respect to the entire sample, and for communicationenhancing practices, for which we find a larger effect. Estimates in the second column show that compared with other teachers, the "Heavy users" obtain better results in terms of student achievement when they employ ICT for media education and for backstage activities, but when they use ICT for knowledge transmission in the classroom, the positive effect on student performance disappears.

Overall, estimates in Table 7 show that our main results discussed in the previous sections are not driven by teachers who are particularly keen on - or familiar with - the use of ICT.

\section{TABLE 7 AROUND HERE}

As a second robustness check, we replicate estimates employing a different dataset, which allows us to use a within-teacher within-student estimator. We employ data from the 2011 Trends in International Math and Science Study (TIMMS) for $8^{\text {th }}$ grade Italian students (who are two years younger than our students). ${ }^{13}$ TIMSS data contain information on student achievement in math and science and detailed information on the corresponding teachers. Because in Italy, in the $8^{\text {th }}$ grade, these subjects are taught by the same teacher, we reach identification exploiting the variation in the use of ICT-related teaching methods in different subjects taught by the same teacher to the same students.

The TIMSS survey contains two questions asking teachers information about the students' use of PCs in class. The first one covers primarily activities that require each student to have a computer and perform assignments such as looking up ideas and information or processing and analyzing data. The second one is related to the frequency of the use in class of specific software. ${ }^{14}$ These questions refer to activities that are similar to those included in the teaching practice we have defined above as active involvement by students during lessons, for instance

\footnotetext{
${ }^{13}$ TIMMS data are available for 34 countries. However, we use data only for Italy because we want to compare estimation results with those obtained using our dataset.

14 The precise wording of the first question is as follows:

How frequently (daily or almost daily; once or twice a week; once or twice a month; never or almost never) do you ask your students to use a PC to do the following activities during math/science lessons? i. Practice skills and information; ii. Look up ideas and information; iii. Process and analyze data. The second question is as follows: When you teach math/science in this class, how do you use software for teaching math/science? The possible answers are the following: $i$. As a basic resource during lessons; ii. as a supplementary resource; iii. not used.
} 
using general or specific software or explaining how to use websites to study or online encyclopedias.

To aggregate them, we built two dummy variables (one for math and one for science) taking the value of one when the teacher asks students to use a PC "daily or almost daily" or "once or twice a week" or when she uses software for teaching as a basic or supplementary resource.

We estimate a regression similar to the one specified in equation [5]. However, given that the same teacher teaches the two subjects, we can fully control for subject-invariant unobserved teacher characteristics that influence both ICT-related teaching method adoption and students' performance exploiting within-student within-teacher variation (Metzler and Woessmann 2012).

In the preferred specification, we controlled for several other subject-specific variables both at the teacher and at the student level. ${ }^{15}$

The results are displayed in Table 8. In columns (1) to (3), we consider one practice at a time, we add all of them in column (4) and, finally, we consider the aggregated dummy defined above, which is our preferred specification. Despite the different dataset, subjects and student grade, they confirm our previous results: In column (5), we see that ICT-related teaching practices requiring active involvement by students during lessons have a negative effect on their performance.

\section{TABLE 8 AROUND HERE}

Overall, estimates utilizing TIMSS data, where we can fully control for teacher subjectinvariant characteristics, are in line with our previous results, suggesting that the rich set of controls for observable teacher characteristics and of proxies for their unobservable traits (e.g., motivation or innate ability in the use of ICT) allows us to properly control for unobserved teacher heterogeneity.

\footnotetext{
${ }^{15}$ Teacher-level variables are: weekly hours of teaching, self-evaluation of own ability to teach, no computer-based teaching methods (e.g., asking students to memorize facts, principles, rules or procedures or to relate the lesson to their daily lives), homework frequency and length and subject-specific training. Student subject-specific variables refer to self-evaluation of one's own performance and to attitudes toward the subject.
} 


\section{Conclusion}

ICT has progressively acquired a prominent role in teaching and learning. Most countries have made huge public investments in the purchase and maintenance of ICT related educational devices. As a result, the majority of developed countries have reached high rates of school ICT access.

However, empirical evidence on the effects of ICT equipment and software is mixed. On the one hand, some studies find negative or null effects, hence concluding that the mere availability of ICT is not enough to improve student achievement (Angrist and Lavy 2002, Goolsbee and Guryan 2006, Leuven et al. 2007, OECD 2015). On the other hand, there is some experimental evidence showing that higher achievement is linked to ICT technology, especially in the case of computer-assisted instruction in developing countries - where computers replace lower quality traditional instruction - and for math (Bulman and Fairlie 2015). A couple of metaanalyses reviewing designed experiments also find this positive effect of ICT use in schools (Kulik 2003, Means et al. 2009).

Among the channels through which the positive effect of ICT in schools arises, there is its impact on students' motivations and on their attitudes toward technology or the subject matter, thus fostering indirectly student learning (Kiboss 2000). ICT allows the teacher to get closer to the students by using a tool that is very familiar to them also outside the classroom. The actual practice that teachers make of ICT and their ability to integrate it into the teaching process is then a key issue (UNESCO 2000), which may reconcile the existing mixed evidence on the effectiveness of ICT on student achievement. Indeed, educational research has clearly pointed out that teachers are crucial in determining the way ICT is adopted and used inside and outside the classroom (OECD 2001) and complementarities between ICT and teacher skill could counterbalance the negative effect on traditional instruction (Bulman and Fairlie 2015).

In order to evaluate the effect of ICT in schools on the learning outcomes, it is then necessary to look beyond the mere availability and use of ICT, focusing on the type of use that teachers actually make of ICT, namely computer-based teaching practices. This analysis requires a relevant effort in carefully defining ITC-related teaching practices and subsequent data collection.

In this paper, we exploit a unique and rich student-teacher dataset to study the effect of a wide array of these practices on student achievement. To control for different sources of unobserved heterogeneity, we employ a within-student between-subject estimator and control for a huge set of teacher ICT-related characteristics. Furthermore, in some specifications we allow for heterogeneous effects by subject. 
Our main contribution to the existing literature consists in the large number of specific practices considered and on the evaluation of the effect of different sets of practices separately.

The results suggest that ICT-related teaching methods matter for student achievement. More specifically, computer-based teaching practices increase student performance if they help the teacher to obtain more easily course content (and hence they presumably increase teacher's subject-specific knowledge) or if they channel the transmission of knowledge. We find a positive influence of teaching practices aimed at increasing students' awareness of ICT use and at improving their navigation critical skills, developing students' ability to distinguish between relevant and irrelevant material and to access, locate, extract, evaluate and organize digital information. We also find a positive effect of ICT communication-enhancing practices, particularly in the case of math. In this case, the channel may be related to the enhancement of parental awareness of their children achievement or to an easier communication among teachers, favoring the adoption of good practices. Instead, we find a negative effect of practices requiring an active role of students in class in utilizing ICT, particularly in the case of Italian language.

Overall, these results confirm that ICT per se is not necessarily beneficial for student learning, as already shown by previous studies. Furthermore, the new technologies are more effective when they are employed to transmit concepts and knowledge in scientific subjects, while active use by students is particularly detrimental in the humanities, in which the nature of the subject itself seems to favor a less productive use of ICT and the Internet. Based on these results, policy makers should be cautious regarding massive investments that focus on an active use of ICTs by students. This does not mean, however, that policy makers should disinvest in this domain. Indeed, our results call for more investment in well-designed pilot interventions assessed through randomized controlled trials, in order to get accurate information about the conditions that render students' active use of ICTs beneficial.

Acknowledgement. We are grateful to Daniele Checchi, Tommaso Frattini, Michele Pellizzari and Vincenzo Scoppa for valuable discussions, to Marc Piopiunik, Mario Padula and the participants at the 2015 SOLE-EALE conference (Montreal), 2015 ICEEE congress (Salerno), 2014 AIEL conference (Pisa) and seminar at the Department of Economics of the University of Alcala for useful suggestions. 


\section{References}

Angrist, Joshua., and Victor Lavy. 2002. "New Evidence on Classroom Computers and Pupil Learning.” Economic Journal 112(482):735-765.

Argentin, Gianluca, Marco Gui, and Chiara Tamanini. 2013. "A scuola di competenza digitale. Il ruolo degli insegnanti nell'uso delle ICT degli studenti." Scuola Democratica 1(1):79-103.

Aslam, Monazza, and Geeta Kingdon. 2011. "What can teachers do to raise pupil achievement?" Economics of Education Review 30(3): 559-574.

Balanskat, Anja, Roger Blamire, and Stella Kefala. 2006. “The ICT Impact Report. A Review of Studies of ICT impact on schools in Europe." European Schoolnet.

Banerjee, Abhijit V., Shawn Cole, Esther Duflo, and Leigh L. Linden. 2007. "Remedying education: Evidence from two randomized experiments in India." Quarterly Journal of Economics 122 (3):1235-1265.

Barrera-Osorio, Felipe, and Leigh L. Linden. 2009. "The use and misuse of computers in education: evidence from a randomized experiment in Colombia.” The World Bank Policy Research Working Paper Series 4836.

Barrow, Lisa, Lisa Markman, and Cecilia E. Rouse. 2009. “Technology's edge: The educational benefits of computer-aided instruction." American Economic Journal: Economic Policy $1(1): 52-74$.

Biagi, Federico, and Massimo Loi. 2013. "Measuring ICT Use and Learning Outcomes: evidence from recent econometric studies." European Journal of Education 48(1):28-42.

Bulman, George, and Robert W. Fairlie. 2015. "Technology and Education: Computers, Software, and the Internet.” CESifo Working Paper 5570.

Calvani, Antonio, Antonio Fini, Maria Ranieri, and Patrizia Picci. 2012. "Are young generations in secondary school digitally competent? A study on Italian teenagers." Computers \& Education 58(2):797-807.

Checchi, Daniele, Enrico Rettore, and Silvia Girardi. 2015. "ICT technology and learning: an

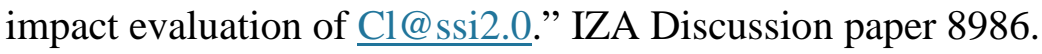

Chien, Sung-Pei, Hsin-Kai Wu, and Ying-Shao Hsu. 2014. "An investigation of teachers' beliefs and their use of technology-based assessments." Computers in Human Behavior $31: 198-210$. 
Condie, Rae, and Bob Munro. 2007. "The impact of ICT in schools: Landscape review." Quality in Education Centre. University of Strathclyde.

Cox, Margaret, Mary Webb, Chris Abbott, Barry Blakeley, Tony Beauchamp, and Valerie Rhodes. (2003). ICT and pedagogy: A review of the research literature. ICT in Schools Research and Evaluation Series No. 18.

Cristia, Julia P., Pablo Ibarrarán, Santiago Cueto, Ana Santiago, and Eugenio Severín. 2012. “Technology and Child Development: Evidence from the One Laptop per Child Program.” IZA Discussion Papers 6401.

Cunningham, Mark, Kirstin Kerr, Rhona McEune, Paula Smith, and Sue Harris. 2003. "Laptops for Teachers: An Evaluation of the First Year of the Initiative." ICT in schools research and evaluation series, No.19. National Foundation for Educational Research and BECTA.

Dee, Thomas S. 2005. “A teacher like me: Does race, ethnicity, or gender matter?.” American Economic Review 95(2):158-165.

Dee, Thomas S. 2007. "Teachers and the gender gaps in student achievement." Journal of Human Resources 42(3):528-554.

Digregorio, Peter, and Karen Sobel-Lojeski. 2009. "The effects of interactive whiteboards (IWBs) on student performance and learning: A literature review." Journal of Educational Technology Systems 38(3):255-312.

Eurydice. 2011. "Key Data on Learning and Innovation through ICT at School in Europe." Education, Audiovisual and Culture Executive Agency (EACEA P9 Eurydice).

European Commission. 2013. "Survey of Schools: ICT in Education. Benchmarking Access, Use and Attitudes to Technology in Europe's Schools. Final Report." European Commission: Brussels.

Fairlie Robert W., and Jonathan Robinson. 2013. "Experimental Evidence on the Effects of Home Computers on Academic Achievement among Schoolchildren." American Economic Journal: Applied Economics 5(3):211-40.

Falck, Oliver, Constantin Mang, and Ludger Woessmann. 2015. "Virtually No Effect? Different Uses of Classroom Computers and their Effect on Student Achievement." IZA Discussion Papers 8939. 
Fuchs, Thomas, and Ludger Woessmann. 2004. "Computers and Student Learning: Bivariate and Multivariate Evidence on the Availability and Use of Computers at Home and at school." CESifo Working Paper No. 1321.

Goolsbee, Austan, and Jonathan Guryan. 2006. "The Impact of Internet Subsidies in Public Schools", Review of Economics and Statistics 88(2):336-347.

Gray, Lucinda, Nina Thomas, and Laurie Lewis. 2010. “Teachers' Use of Educational Technology in U.S. Public Schools: 2009” National Center for Education Statistics. Institute of Education Sciences. U.S. Department of Education. Washington, DC.

Gui, Marco, and Gianluca Argentin. 2011. "Digital skills of internet natives: Different forms of digital literacy in a random sample of northern Italian high school students." New Media \& Society 13(6):963-980.

Hanushek, Eric A. 2004. "What if there are no 'best practices'?." Scottish Journal of Political Economy 51(2):156-172.

Hanushek, Eric A., and Steven G. Rivkin. 2012. "The distribution of teacher quality and implications for policy." Annual Review of Economics 4:131-157.

Higgins, Steve, Chris Falzon, Ian Hall, David Moseley, Fay Smith, H. Smith, and Kate Wall. 2005. "Embedding ICT in the Literacy and Numeracy Strategies: Final Report." University of Newcastle. Becta.

Kane, Thomas J., Eric S. Taylor, John H. Tyler, and Amy L. Wooten. 2011. "Identifying Effective Classroom Practices Using Student Achievement Data." Journal of Human Resources 46(3):587-613.

Kiboss, Joel K. 2000. “Teacher/pupil perspectives on computer-augmented physics lessons on measurement in Kenyan secondary schools." Journal of Information Technology for Teacher Education 9(2):199-218.

Kulik, James A. 2003. "Effects of Using Instructional Technology in Elementary and Secondary schools: What Controlled Evaluation Studies Say?." Menlo Park, CA. SRI International.

Lavy, Victor. 2011. "What Makes an Effective Teacher? Quasi-Experimental Evidence". NBER Working Paper 16885. 
Lavy, Victor. 2015. "Do Differences in Schools' Instruction Time Explain International Achievement Gaps? Evidence from Developed and Developing Countries”. Economic Journal 125(588): F397-F424.

Lee, Youngju, and Jihyun Lee. 2014. "Enhancing pre-service teachers' self-efficacy beliefs for technology integration through lesson planning practice." Computers \& Education 73:121128.

Leuven, Edwin, Mikael Lindahl, Hessel Oosterbeek, and Dinand Webbink. 2007. "The Effect of Extra Funding for Disadvantaged Pupils on Achievement", Review of Economics and Statistics 89(4): 721-736.

Machin, Stephen, Sandra McNally, and Olmo Silva. 2007. "New Technology in Schools: Is There a Payoff?.” Economic Journal 117(522):1145-1167.

Means, Barbara, Yukie Toyama, Robert Murphy, Marianne Bakia, and Karla Jones. 2009. "Evaluation of evidence-based practices in online learning: a meta-analysis and review of online learning studies." Department of Education, Office of Planning, Evaluation, and Policy Development. Washington, DC, U.S.

Metzler, Johannes, and Ludger Woessmann. 2012. "The impact of teacher subject knowledge on student achievement: Evidence from within-teacher within-student variation." Journal of Development Economics 99(2):486-496.

OECD. 2001. "The Practice and Professional Development of Teachers, in Learning to Change: ICT in Schools". Paris: OECD publishing.

OECD. 2011. "PISA 2009 Results: Students on Line: Digital Technologies and Performance." (Volume VI). Paris: OECD publishing.

OECD. 2013. "Review of the Italian strategy for digital schools." Paris: OECD publishing.

OECD. 2015. "Students, Computers and Learning: Making the Connection, PISA." Paris: OECD publishing.

Pagani, Laura, Gianluca Argentin, Marco Gui, and Luca Stanca. 2015. "The Impact of Digital Skills on Educational Outcomes: Evidence from Performance Tests". University of Milan Bicocca. DEMS Working Paper No. 304.

Ramboll Management. 2006. E-Learning Nordic 2006: Impact of ICT on education, Ramboll Management, Copenaghen. 
Rouse, Cecilia E. and Alan B. Krueger. 2004. "Putting computerized instruction to the test: a randomized evaluation of a "scientifically based" reading program." Economics of Education Review 23(4):323-338.

Scherer, Ronny, Fazilat Siddiq, and Timothy Teo. 2015. "Becoming more specific: Measuring and modeling teachers' perceived usefulness of ICT in the context of teaching and learning." Computers \& Education 88:202-214.

Schwerdt, Guido, and Amelie C. Wuppermann. 2011. "Is traditional teaching really all that bad? A within-student between-subject approach." Economics of Education Review 30(2):365-379.

Smith, Fay, Frank Hardman, and Steve Higgins. 2006. "The impact of interactive whiteboards on teacher-pupil interaction in the National Literacy and Numeracy Strategies." British Educational Research Journal 32(3):443-457.

UNESCO. 2000. Dakar Framework For Action. World Economic Forum.

Van Deursen, Alexander J.A.M., and Jan A.G.M. Van Dijk. 2009. "Using the Internet: Skill related problems in users' online behavior." Interacting with Computers 21(5):393-402.

Van Klaveren, Chris. 2011. "Lecturing style teaching and student performance." Economics of Education Review 30(4):729-739.

Zakharov, Andrey, Martin Carnoy, and Prashant Loyalka. 2104. "Which teaching practices improve student performance on high-stakes exams? Evidence from Russia.” International Journal of Educational Development 36:13-21. 
Table 1

Teacher and student characteristics by subject

\begin{tabular}{|c|c|c|c|}
\hline VARIABLES & $\begin{array}{c}(1) \\
\text { Italian } \\
\text { Mean } \\
(\mathrm{SD}) \\
\end{array}$ & $\begin{array}{c}(2) \\
\text { Math } \\
\text { Mean } \\
(\mathrm{SD}) \\
\end{array}$ & $\begin{array}{c}(3) \\
\text { Difference } \\
(1)-(2) \\
(\mathrm{SE}) \\
\end{array}$ \\
\hline \multicolumn{4}{|c|}{ Panel A: Teacher characteristics } \\
\hline Male & $\begin{array}{c}0.237 \\
(0.426)\end{array}$ & $\begin{array}{c}0.134 \\
(0.340)\end{array}$ & $\begin{array}{l}.103 \\
(.018)\end{array}$ \\
\hline Age & $\begin{array}{c}49.11 \\
(9.697)\end{array}$ & $\begin{array}{c}51.29 \\
(8.260)\end{array}$ & $\begin{array}{l}-2.17 \\
(.432)\end{array}$ \\
\hline Phd & $\begin{array}{c}0.258 \\
(0.438)\end{array}$ & $\begin{array}{c}0.192 \\
(0.394)\end{array}$ & $\begin{array}{c}.065 \\
(.020)\end{array}$ \\
\hline College final grade & $\begin{array}{c}108.4 \\
(3.297)\end{array}$ & $\begin{array}{c}98.10 \\
(8.344)\end{array}$ & $\begin{array}{l}10.25 \\
(.304)\end{array}$ \\
\hline Permanent contract & $\begin{array}{c}0.775 \\
(0.418)\end{array}$ & $\begin{array}{c}0.917 \\
(0.276)\end{array}$ & $\begin{array}{l}-.141 \\
(.017)\end{array}$ \\
\hline Weekly teaching hours & $\begin{array}{c}6.540 \\
(1.979)\end{array}$ & $\begin{array}{c}4.531 \\
(1.728)\end{array}$ & $\begin{array}{c}2.00 \\
(.089)\end{array}$ \\
\hline Experience (years) & $\begin{array}{c}19.67 \\
(11.01)\end{array}$ & $\begin{array}{c}23.03 \\
(8.724)\end{array}$ & $\begin{array}{l}-3.361 \\
(.477)\end{array}$ \\
\hline Tenure (years) & $\begin{array}{c}9.733 \\
(8.125)\end{array}$ & $\begin{array}{c}11.80 \\
(8.858)\end{array}$ & $\begin{array}{l}-2.07 \\
(.408)\end{array}$ \\
\hline \multicolumn{4}{|l|}{ Motivation for teaching } \\
\hline Responding to my need & $\begin{array}{c}0.123 \\
(0.329)\end{array}$ & $\begin{array}{l}0.0184 \\
(0.135)\end{array}$ & $\begin{array}{c}0.105 \\
(0.0121)\end{array}$ \\
\hline Passion for the subject & $\begin{array}{c}0.333 \\
(0.472)\end{array}$ & $\begin{array}{c}0.470 \\
(0.499)\end{array}$ & $\begin{array}{c}-0.137 \\
(0.0233)\end{array}$ \\
\hline Passion for teaching & $\begin{array}{c}0.278 \\
(0.448)\end{array}$ & $\begin{array}{c}0.252 \\
(0.435)\end{array}$ & $\begin{array}{c}0.0253 \\
(0.0212)\end{array}$ \\
\hline Willing to work among youth & $\begin{array}{c}0.160 \\
(0.367)\end{array}$ & $\begin{array}{c}0.104 \\
(0.305)\end{array}$ & $\begin{array}{c}0.0565 \\
(0.0162)\end{array}$ \\
\hline Lack of other job opportunities & $\begin{array}{c}0.106 \\
(0.308)\end{array}$ & $\begin{array}{c}0.156 \\
(0.363)\end{array}$ & $\begin{array}{l}-0.0495 \\
(0.0161)\end{array}$ \\
\hline \multicolumn{4}{|c|}{ Panel B: Student subject-specific variables } \\
\hline INVALSI test score & $\begin{array}{l}78.055 \\
(11.38)\end{array}$ & $\begin{array}{c}58.24 \\
(17.18)\end{array}$ & $\begin{array}{l}19.81 \\
(.699)\end{array}$ \\
\hline $1^{\text {st }}$ term grade & $\begin{array}{c}6.592 \\
(0.965)\end{array}$ & $\begin{array}{c}6.330 \\
(1.440)\end{array}$ & $\begin{array}{c}.262 \\
(.058)\end{array}$ \\
\hline Familiarity with INVALSI-type tests & $\begin{array}{c}0.450 \\
(0.498)\end{array}$ & $\begin{array}{c}0.262 \\
(0.440)\end{array}$ & $\begin{array}{c}.189 \\
(.022)\end{array}$ \\
\hline Subject important in life & $\begin{array}{c}0.505 \\
(0.500)\end{array}$ & $\begin{array}{c}0.889 \\
(0.314)\end{array}$ & $\begin{array}{c}-0.385 \\
(0.020)\end{array}$ \\
\hline Subject important to learn other subjects & $\begin{array}{c}0.461 \\
(0.499)\end{array}$ & $\begin{array}{c}0.865 \\
(0.342)\end{array}$ & $\begin{array}{c}-0.404 \\
(0.0205)\end{array}$ \\
\hline Subject important for future school career & $\begin{array}{c}0.457 \\
(0.498)\end{array}$ & $\begin{array}{c}0.652 \\
(0.477)\end{array}$ & $\begin{array}{c}-0.195 \\
(0.0234)\end{array}$ \\
\hline Subject important for future work & $\begin{array}{c}0.472 \\
(0.500)\end{array}$ & $\begin{array}{c}0.781 \\
(0.414)\end{array}$ & $\begin{array}{l}-0.309 \\
0.0220\end{array}$ \\
\hline Observations & 868 & 868 & 1736 \\
\hline
\end{tabular}


Table 2

Teacher ICT-related variables. Summary statistics by subject

\begin{tabular}{lccc}
\hline & Italian & Math & Difference \\
Variable & Mean & Mean & $(1)-(2)$ \\
& $(\mathrm{SD})$ & $(\mathrm{SD})$ & $(\mathrm{SE})$ \\
\hline
\end{tabular}

ICT knowledge and training

Number of correct answers in ICT test (from 1 to 15)

$\begin{array}{ccc}8.74 & 8.51 & 0.229 \\ (0.080) & (0.083) & (0.11) \\ 6.029 & 6.438 & -0.409 \\ (1.511) & (1.686) & (0.0768) \\ 0.364 & 0.551 & -0.186 \\ (0.481) & (0.498) & (0.023)\end{array}$

Number of hours on internet everyday

ICT use in spare time

Use pc every day at home

$\begin{array}{ccc}1.508 & 1.267 & 0.241 \\ (0.902) & (0.866) & (0.042) \\ 0.926 & 0.895 & 0.0311 \\ (0.261) & (0.307) & (0.014) \\ 0.374 & 0.289 & 0.0853 \\ (0.484) & (0.454) & (0.023)\end{array}$

ICT-related beliefs

In favor of ICT use in preparing lecture

$0.788 \quad 0.568 \quad 0.22$

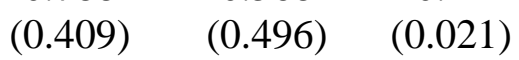

In favor of ICT use in teaching

$0.643 \quad 0.615 \quad 0.027$

$\begin{array}{lll}(0.479) & (0.487) \quad(0.023)\end{array}$

In favor of ICT use involving students

$0.407 \quad 0.523 \quad-0.116$

$(0.491) \quad(0.500) \quad(0.023)$

Think ICT introduced important change in teaching

$\begin{array}{lll}0.324 & 0.303 & 0.021\end{array}$

$\begin{array}{lll}(0.468) & (0.460) \quad(0.022)\end{array}$

Think ICT had very positive effect on her own teaching

$\begin{array}{lll}0.0553 & 0.151 & -0.95\end{array}$

$\begin{array}{lll}(0.229) \quad(0.358) & (0.014)\end{array}$

Think my school is in favor of ICT adoption

$0.495 \quad 0.669 \quad-0.174$

$\begin{array}{lll}(0.500) & (0.471) \quad(0.0233)\end{array}$

Think my school is hostile to ICT adoption

$\begin{array}{lll}0.136 & 0.0611 & 0.0749\end{array}$

$\begin{array}{lll}(0.343) & (0.240) \quad(0.0142)\end{array}$

Think my colleagues are in favor of ICT use in our school

$\begin{array}{ccc}0.336 & 0.368 & -0.0311 \\ (0.473) & (0.482) & (0.0229)\end{array}$

Think my colleagues are in favor of ICT use in our school
0.142
0.108
0.0334
(0.349)
(0.311)
$(0.0159)$

ICT use in teaching

Number of hours using the interactive multimedia board

$\begin{array}{ccc}0.369 & 0.951 & -0.581 \\ (1.217) & (3.157) & (0.114) \\ 1.586 & 0.942 & 0.644 \\ (3.088) & (0.053) & (0.117) \\ 2.66 & 2.24 & 0.415 \\ (6.62) & (5.34) & 0.288\end{array}$


Table 3

Principal components analysis - Rotated factor loadings (pattern matrix)

\begin{tabular}{|c|c|c|c|c|c|}
\hline $\mathrm{Fac}$ & Factor2 & Factor3 & Factor4 & Factor5 & \\
\hline Knowledge & Media & $\begin{array}{l}\text { Active } \\
\text { Antyement }\end{array}$ & $\begin{array}{l}\text { Backstage } \\
\text { activities }\end{array}$ & Communication & Uniqueness \\
\hline
\end{tabular}

Use slides during lessons

\begin{tabular}{lccccc}
$\mathbf{0 . 8 7 5 9}$ & 0.0863 & 0.1143 & 0.0855 & 0.0571 & 0.2017 \\
$\mathbf{0 . 8 7 2 6}$ & 0.0484 & 0.1765 & 0.0405 & 0.0681 & 0.1988 \\
$\mathbf{0 . 6 4 7 5}$ & 0.1225 & 0.2414 & 0.2469 & 0.162 & 0.4202 \\
$\mathbf{0 . 6 9 1 6}$ & 0.1885 & 0.2432 & 0.2018 & 0.0682 & 0.3817 \\
0.1828 & 0.078 & 0.1272 & $\mathbf{0 . 7 8 9 4}$ & 0.0232 & 0.3206 \\
0.0488 & -0.0396 & 0.0632 & $\mathbf{0 . 7 0 9 8}$ & 0.2684 & 0.4162 \\
$\mathbf{0 . 4 1 2 7}$ & 0.0703 & 0.0509 & $\mathbf{0 . 5 5 1 5}$ & 0.0386 & 0.5165 \\
0.067 & $\mathbf{0 . 8 3 3 5}$ & 0.16 & 0.0247 & 0.0837 & 0.2676 \\
0.1032 & $\mathbf{0 . 8 4 9 8}$ & 0.0548 & 0.0049 & 0.0592 & 0.2607 \\
0.2035 & $\mathbf{0 . 6 3 2 6}$ & 0.1774 & 0.0633 & 0.1041 & 0.5121 \\
0.083 & $\mathbf{0 . 5 9 6 1}$ & $\mathbf{0 . 4 5 5 9}$ & -0.0296 & 0.0653 & 0.4248 \\
0.0723 & $\mathbf{0 . 5 5 7 6}$ & $\mathbf{0 . 4 8 9 9}$ & 0.2032 & -0.0625 & 0.3986 \\
0.1196 & 0.3761 & $\mathbf{0 . 6 0 6 2}$ & 0.2486 & -0.1373 & 0.3961 \\
0.2358 & 0.1702 & $\mathbf{0 . 7 8 4 6}$ & 0.0611 & 0.1075 & 0.2845 \\
0.2293 & 0.0607 & $\mathbf{0 . 7 8 1}$ & -0.0259 & 0.1842 & 0.2991 \\
0.2585 & 0.2542 & $\mathbf{0 . 6 2 6 2}$ & 0.2303 & 0.0585 & 0.42 \\
0.1608 & 0.1073 & 0.1524 & 0.1574 & $\mathbf{0 . 6 7 8 9}$ & 0.4537 \\
0.0836 & 0.0798 & 0.0795 & 0.1241 & $\mathbf{0 . 7 3 7 3}$ & 0.4213 \\
0.3854 & 0.1673 & 0.095 & -0.0274 & $\mathbf{0 . 4 3 8 3}$ & 0.6215 \\
\hline & & & & &
\end{tabular}


Table 4

Effect of ICT-related teaching practices on student achievement

Within-student between-subject estimator

TEACHING PRACTICE

Knowledge transmission

Media education

Active involvement

Backstage activities

Communication

Teacher controls

Student subject-specific controls

Observations

R-squared

Number of ids

F-test ICT practices
(1)

(2)

0.238

(0.146)

$0.204 * * *$

$(0.0752)$

$-0.262 * *$

(0.105)

0.0697

(0.0663)

$0.287 * * *$

(0.0945)

$0.263^{* *}$

(0.115)

$0.199 * * *$

(0.0624)

$-0.284 * * *$

(0.0863)

0.0578

(0.0577)

$0.281 * * *$

(0.0763)

$\begin{array}{ll}\text { YES } & \text { YES } \\ \text { NO } & \text { YES }\end{array}$

$\begin{array}{cc}1,736 & 1,736 \\ 0.246 & 0.313 \\ 868 & 868 \\ 3.936 & 5.551\end{array}$

Notes: $* * * \mathrm{p}<0.01, * * \mathrm{p}<0.05, * \mathrm{p}<0.1$. Clustered standard errors in parentheses (number of clusters: 47). All specifications include a constant and a subject dummy. Teacher controls are: male, age, $\mathrm{PhD}$, college final grade, permanent contract, weekly teaching hours, experience, experience squared, tenure, tenure squared, motivation dummies, ICT critical knowledge test score, ICT subjective assessment, ICT related training, daily number of hours on the internet, a dummy for Facebook profile, a dummy for daily use of pc at home, ICT-related beliefs. Student subject-specific controls are: $1^{\text {st }}$ term grade, familiarity with INVALSI-type tests and motivations to study each subject. 
Table 5

Effect of general use of ICT on student achievement

Within-student between-subject estimator

VARIABLES

(1)

(2)

(3)

(4)

(5)

Standardized sum of factors

0.0148

(0.085)

Sum of single practices

(0.0137)

Number of intensively used practices

0.00254

(0.0308)

At least one practice used intensively

$(0.321)$

Use ICT in class for at least one hour in a month

Teacher controls

Student subject-specific controls

$\begin{array}{lllll}\text { YES } & \text { YES } & \text { YES } & \text { YES } & \text { YES } \\ \text { YES } & \text { YES } & \text { YES } & \text { YES } & \text { YES }\end{array}$

Observations

$\begin{array}{lllll}1,736 & 1,736 & 1,736 & 1,736 & 1,736\end{array}$

R-squared

$0.253 \quad 0.256$

0.253

$0.259 \quad 0.258$

Number of ids

$868 \quad 868$

868

$868 \quad 868$

Notes: $* * * \mathrm{p}<0.01, * * \mathrm{p}<0.05, * \mathrm{p}<0.1$. Clustered standard errors in parentheses (number of clusters: 47). All specifications include a constant and a subject dummy. Teacher controls are: male, age, $\mathrm{PhD}$, college final grade, permanent contract, weekly teaching hours, experience, experience squared, tenure, tenure squared, motivation dummies, ICT critical knowledge test score, ICT subjective assessment, ICT related training, daily number of hours on the internet, a dummy for Facebook profile, a dummy for daily use of pc at home, ICT-related beliefs. Student subject-specific controls are: $1^{\text {st }}$ term grade, familiarity with INVALSI-type tests and motivations to study each subject. 


\section{Table 6}

Effect of ICT-related teaching practices on student achievement. Subject specific coefficients Within-student between-subjects estimator

\section{VARIABLES}

Knowledge transmission $x$ Italian language

$-0.102 \quad(0.194)$

Media education x Italian language

$-0.0581 \quad(0.157)$

Active involvement $x$ Italian language

$-0.702 * * *$

Backstage activities x Italian language

$-0.054$

Communication $x$ Italian language

0.220

Knowledge transmission $\mathrm{x}$ math

$0.404 * * *$

Media education x math

0.0109

Active involvement $\mathrm{x}$ math

$-0.152$

Backstage activities $\mathrm{x}$ math

$-0.0598 \quad(0.099)$

Communication $\mathrm{x}$ math

Teacher controls

YES

Student subject-specific controls

YES

Observations

R-squared

0.335

Number of ids

868

Notes: $* * * \mathrm{p}<0.01, * * \mathrm{p}<0.05, * \mathrm{p}<0.1$. Clustered standard errors in parentheses (number of clusters: 47). All specifications include a constant and a subject dummy. Teacher controls are: male, age, $\mathrm{PhD}$, college final grade, permanent contract, weekly teaching hours, experience, experience squared, tenure, tenure squared, motivation dummies, ICT critical knowledge test score, ICT subjective assessment, ICT related training, daily number of hours on the internet, a dummy for Facebook profile, a dummy for daily use of pc at home, ICT-related beliefs. Student subject-specific controls are: $1^{\text {st }}$ term grade, familiarity with INVALSI-type tests and motivations to study each subject. 
Table 7

Heterogeneous effects by group of teachers

Within-student between-subject estimator

VARIABLES

Knowledge transmission

Media education

Active involvement

Backstage activities

Communication

Knowledge transmission $\mathrm{x}$ believer

Media education $\mathrm{x}$ believer

Active involvement $\mathrm{x}$ believer

Backstage activities $\mathrm{x}$ believer

Communication $\mathrm{x}$ believer

Knowledge transmission $\mathrm{x}$ heavy user

Media education x heavy user

Active involvement $\mathrm{x}$ heavy user

Backstage activities $\mathrm{x}$ heavy user

Communication $\mathrm{x}$ heavy user

(1)

(2)

$0.370 * * *$

(0.116)

$0.321 * * *$

(0.0856)

$-0.491 * * *$

(0.153)

$0.169 * * *$

(0.0607)

$0.434 * * *$

(0.0743)

$-0.117$

(0.225)

$-0.305^{* * *}$

(0.110)

$-0.400$

(0.267)

$-0.634$

(0.546)

$0.525^{* *}$

(0.255)

$-0.598 * * *$

(0.110)

$0.202 * *$

(0.0754)

$0.315^{*}$

$(0.174)$

$0.778 * * *$

(0.189)

0.115

(0.207)

Teacher controls

YES

Student subject-specific controls

YES

Observations

1,736

0.341

868
1,736

0.379

868
Number of ids

Notes: $* * * \mathrm{p}<0.01, * * \mathrm{p}<0.05, * \mathrm{p}<0.1$. Clustered standard errors in parentheses (number of clusters: 47). All specifications include a constant and a subject dummy. Teacher controls are: male, age, $\mathrm{PhD}$, college final grade, permanent contract, weekly teaching hours, experience, experience squared, tenure, tenure squared, motivation dummies, ICT critical knowledge test score, ICT subjective assessment, ICT related training, daily number of hours on the internet, a dummy for Facebook profile, a dummy for daily use of pc at home, ICT-related beliefs. Student subject-specific controls are: $1^{\text {st }}$ term grade, familiarity with INVALSI-type tests and motivations to study each subject. 
Table 8

Effect of active student involvement - TIMMS data

Within-teacher within-student estimator

\begin{tabular}{|c|c|c|c|c|c|}
\hline VARIABLES & (1) & (2) & (3) & (4) & (5) \\
\hline Process and analyze data & $\begin{array}{l}-0.0715 \\
(0.053)\end{array}$ & & & $\begin{array}{c}-0.00937 \\
(0.0550)\end{array}$ & \\
\hline Practice skills and information & & $\begin{array}{c}-0.183 * * * \\
(0.038)\end{array}$ & & $\begin{array}{c}-0.186 * * * \\
(0.0544)\end{array}$ & \\
\hline Look up ideas and information & & & $\begin{array}{c}0.0156 \\
(0.0590)\end{array}$ & $\begin{array}{c}0.0462 \\
(0.0420)\end{array}$ & \\
\hline $\begin{array}{l}\text { Active students involvement } \\
\text { (dummy variable) }\end{array}$ & & & & & $\begin{array}{l}-0.0567 * \\
(0.0312)\end{array}$ \\
\hline Teacher subject-specific controls & YES & YES & YES & YES & YES \\
\hline Student subject-specific controls & YES & YES & YES & YES & YES \\
\hline Student fixed effect & YES & YES & YES & YES & YES \\
\hline Teacher fixed effect & YES & YES & YES & YES & YES \\
\hline Observations & 6,878 & 6,878 & 6,878 & 6,878 & 6,878 \\
\hline R-squared & 0.083 & 0.085 & 0.083 & 0.086 & 0.082 \\
\hline Number of ids & 3,439 & 3,439 & 3,439 & 3,439 & 3,439 \\
\hline
\end{tabular}

Notes: $* * * \mathrm{p}<0.01, * * \mathrm{p}<0.05, * \mathrm{p}<0.1$. Clustered standard errors in parentheses (number of clusters: 176). All specifications include a constant and a subject dummy. Teacher subjectspecific controls are: weekly hours of teaching, self-evaluation of own ability to teach, not computer-based teaching methods (e.g. ask students to memorize facts, principles, rules or procedures or to relate the lesson to their daily lives), homework frequency and length and subject-specific training. Student subject-specific controls are self-evaluation of own performance and attitudes towards the subject. 

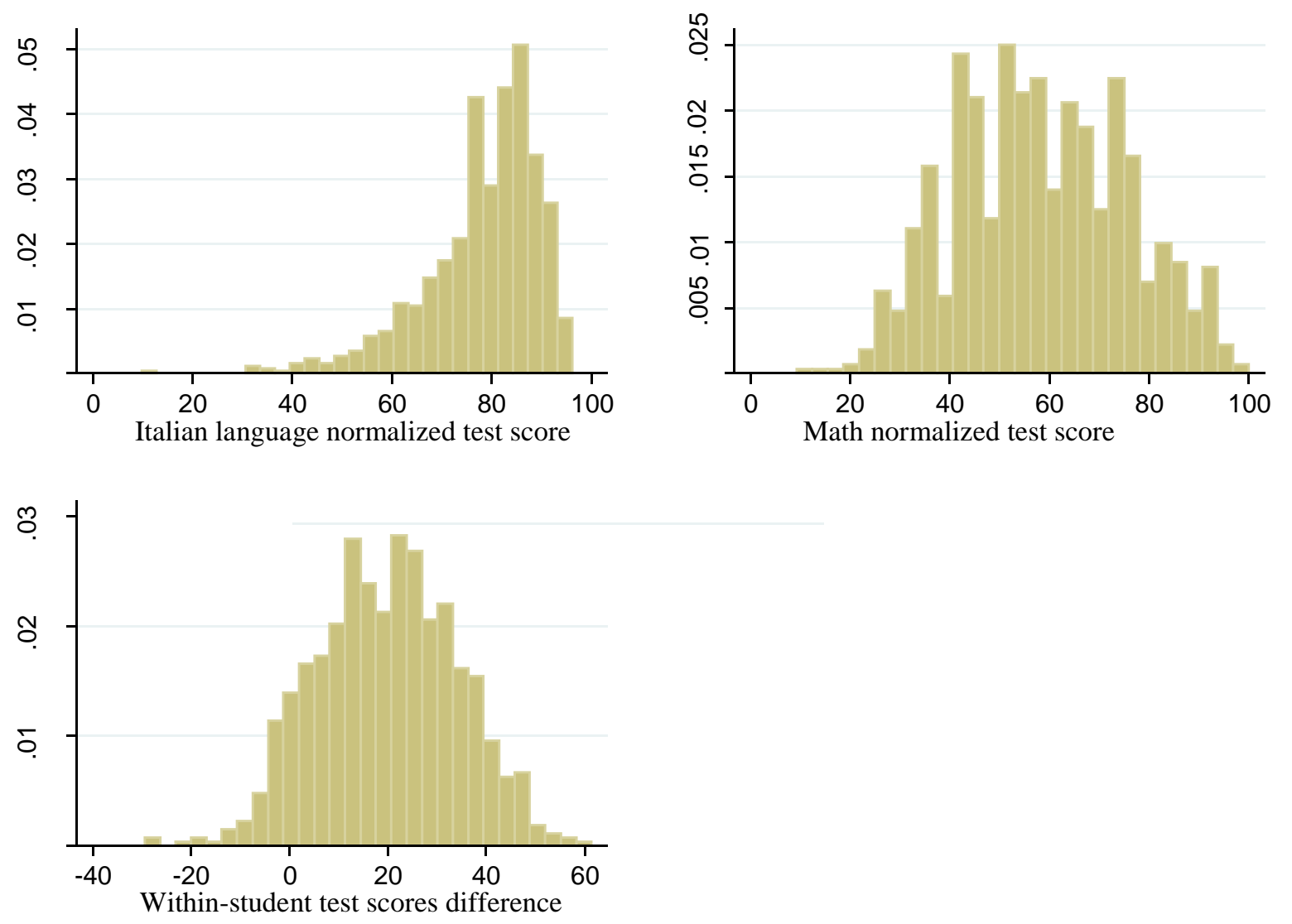

Figure 1

Italian language and math test score distributions and within-student difference. 


\section{Table A1}

Use of ICT-related teaching practices. Summary statistics by subject

Row percentages

\begin{tabular}{|c|c|c|c|c|c|c|c|c|c|c|c|c|c|c|c|}
\hline & \multicolumn{3}{|c|}{ Use slide } & \multicolumn{3}{|c|}{ Use digital material } & \multicolumn{3}{|c|}{ Share files with students } & \multicolumn{3}{|c|}{ Prepare printouts } & \multicolumn{3}{|c|}{ Preparing test } \\
\hline & often & sometime & never & often & sometime & never & often & sometime & never & often & sometime & never & often & sometime & never \\
\hline Italian & 16.36 & 35.02 & 48.62 & 15.78 & 29.84 & 54.38 & 15.55 & 52.19 & 32.26 & 43.78 & 56.22 & 0.00 & 54.61 & 45.39 & 0.00 \\
\hline \multirow[t]{3}{*}{ Math } & 11.06 & 47.12 & 41.82 & 16.59 & 46.08 & 37.33 & 23.62 & 51.38 & 25.00 & 32.95 & 51.27 & 15.78 & 63.94 & 36.06 & 0.00 \\
\hline & \multicolumn{3}{|c|}{$\begin{array}{c}\text { Show web-sites during } \\
\text { lessons }\end{array}$} & \multicolumn{3}{|c|}{$\begin{array}{c}\text { Use internet to prepare a } \\
\text { lecture }\end{array}$} & \multicolumn{3}{|c|}{$\begin{array}{c}\text { Use pc to communicate } \\
\text { with colleagues, students } \\
\text { and families }\end{array}$} & \multicolumn{3}{|c|}{$\begin{array}{l}\text { Exchange teaching } \\
\text { material with colleagues }\end{array}$} & \multicolumn{3}{|c|}{$\begin{array}{l}\text { Attend online training } \\
\text { courses }\end{array}$} \\
\hline & often & sometime & never & often & sometime & never & often & sometime & never & often & sometime & never & often & sometime & never \\
\hline Italian & 7.26 & 53 & 39.75 & 55.41 & 35.14 & 9.45 & 24.08 & 64.29 & 11.64 & 8.41 & 63.48 & 28.11 & 1.61 & 29.49 & 68.89 \\
\hline \multirow[t]{3}{*}{ Math } & 15.21 & 40.9 & 43.89 & 49.42 & 41.47 & 9.1 & 42.17 & 49.65 & 8.18 & 16.71 & 61.18 & 22.12 & 2.53 & 37.21 & 60.25 \\
\hline & \multicolumn{3}{|c|}{$\begin{array}{c}\text { Teach students how to } \\
\text { use online encyclopedias }\end{array}$} & \multicolumn{3}{|c|}{$\begin{array}{c}\text { Teach students how to use } \\
\text { social media }\end{array}$} & \multicolumn{3}{|c|}{$\begin{array}{c}\text { Teach students about } \\
\text { privacy }\end{array}$} & \multicolumn{3}{|c|}{$\begin{array}{c}\text { Use common software } \\
\text { with students }\end{array}$} & \multicolumn{3}{|c|}{$\begin{array}{c}\text { Use specific software } \\
\text { with students }\end{array}$} \\
\hline & often & sometime & never & often & sometime & never & often & sometime & never & often & sometime & never & often & sometime & never \\
\hline Italian & 11.06 & 45.97 & 42.97 & 8.76 & 25.12 & 66.13 & 1.96 & 2.76 & 95.28 & 12.67 & 27.88 & 59.45 & 1.61 & 13.59 & 84.79 \\
\hline \multirow[t]{3}{*}{ Math } & 9.22 & 21.43 & 69.35 & 2.53 & 19.93 & 77.53 & 0 & 4.49 & 95.51 & 31.45 & 37.1 & 31.45 & 17.74 & 29.38 & 52.88 \\
\hline & \multicolumn{3}{|c|}{$\begin{array}{l}\text { Explain how to study } \\
\text { with internet }\end{array}$} & \multicolumn{3}{|c|}{$\begin{array}{l}\text { Explain how to find } \\
\text { groups in internet }\end{array}$} & \multicolumn{3}{|c|}{$\begin{array}{c}\text { Teach how to avoid } \\
\text { viruses }\end{array}$} & \multicolumn{3}{|c|}{$\begin{array}{c}\text { Teach how to evaluate } \\
\text { the reliability of website } \\
\text { content }\end{array}$} & & & \\
\hline & often & sometime & never & often & sometime & never & often & sometime & never & often & sometime & never & & & \\
\hline Italian & 18.09 & 55.76 & 26.15 & 0 & 13.25 & 86.75 & 0 & 4.49 & 95.51 & 8.87 & 52.19 & 38.94 & & & \\
\hline Math & 17.05 & 38.25 & 44.7 & 2.07 & 4.49 & 93.43 & 2.53 & 8.29 & 89.17 & 2.53 & 39.75 & 57.52 & & & \\
\hline
\end{tabular}


Table A2

Use of ICT-related teaching practices by group of teachers. Factor means TEACHING PRACTICE Believer Heavy Users

(SD)

(SD)

Knowledge transmission 1.14 (.60) .69

Media education

0.92 $(1.05)$

Media education (1.47) .46

Active involvement

$$
.66
$$

Backstage activities

.13

Backstage activities

.28

(1.09)

$-.08$

(.79)

Communication

295

N. obs 295 (1.10)

Note: Each factor has been standardized, so the mean and the standard deviation on the whole sample are, respectively, 0 and 1. 